\title{
Residual myocardial dyssynchrony after cardiac resynchronization therapy in patients with and without immediate echocardiographic optimization
}

\author{
(D)Marija Brestovac*, \\ DBlanka Glavaš Konja, \\ (D) Martina Lovrić \\ Benčić, \\ (i) Vlatka Rešković \\ Lukšić, \\ (1)Kristina Gašparović, \\ DSandra Jakšić \\ Jurinjak, \\ (D)Jadranka Šeparović \\ Hanževački
}

University of Zagreb School of Medicine, University Hospital Centre Zagreb, Zagreb, Croatia

RECEIVED:

March 28, 2021

ACCEPTED:

April 2, 2021

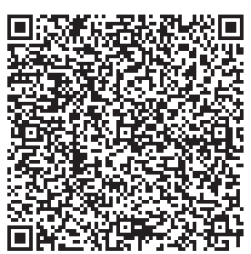

Cardiologia Croatica 2021;16(5-6):202.
KEYWORDS: cardiac resynchronization therapy, dyssynchrony, echocardiographic optimization. CITATION: Cardiol Croat. 2021;16(5-6):202. | https://doi.org/10.15836/ccar2021.202

*ADDRESS FOR CORRESPONDENCE: Marija Brestovac, Klinički bolnički centar Zagreb, Kišpatićeva 12, HR-10000 Zagreb, Croatia. / Phone: +385-99-7742-627 / E-mail: marija.brestovac@gmail.com

ORCID:Marija Brestovac, https://orcid.org/0000-0003-1542-2890 • Blanka Glavaš Konja, https://orcid.org/0000-0003-1134-4856 Martina Lovrić Benčić, https://orcid.org/0000-0001-8446-6120 • Vlatka Rešković Lukšić, https://orcid.org/0000-0002-4721-3236 Kristina Gašparović, https://orcid.org/0000-0002-1191-4831 • Sandra Jakšić Jurinjak, https://orcid.org/0000-0002-7349-6137 Jadranka Šeparović Hanževački, https://orcid.org/0000-0002-3437-6407

||||||||||||||||||||||||||||||||||||||||||||||||||||||||||||||||||||||||||||||||||||||||||||||||||||||||||||||||||||||||||||||||||||

Introduction: Cardiac resynchronization therapy (CRT) is used in the treatment of severe symptomatic heart failure with LBBB. Such patients often have at least one echocardiographic sign of either one type of dyssynchrony, interventricular (VV), intraventricular or atrioventricular (AV), present. It is known that about $30 \%$ of patients are nonresponders to this type of treatment. One of the causes is residual dyssynchrony after CRT device implantation. ${ }^{1,2}$ The aim of this study was to determine whether there is a difference in the presence of any of the echocardiographic signs of dyssynchrony after 6 months of follow up using two different CRT optimization methods

Patients and Methods: We included 147 CRT patients in this study. Each patient underwent full echocardiographic study with assessing signs of dyssynchrony before and 6 months after CRT device implantation. Patients were divided into two groups according to the method of CRT optimization, echocardiographically (ECHO) or electrocardiographically (ECG) guided CRT optimization. In Both groups initially AV and VV delay optimization were set up according to QRS width. On top of this ECHO group was additionally echocardiographically optimized accordingly to echocardiographic signs of dyssynchrony, septal flash (SF) disappearance, A wave truncation and merged E and A waves (AVd) and interventricular mechanical delay (IVMD). After 6 months of follow up residual dyssynchrony was defined as presence of SF, AVd and/or IVMD $>40 \mathrm{~ms}$.

Results: In both groups, a significant reduction of echocardiographic signs of dyssynchrony was observed during the follow-up period. Comparison between the groups showed that residual SF and AVd were less frequent present in the ECHO group and reached statistically significance ( $<<0.01$ for SF and

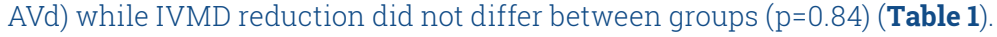

Conclusion: Echocardiographic optimization of CRT is associated with a greater reduction of residual $\mathrm{SF}$ and AV dyssynchrony compared to ECG optimization while no difference in the reduction of IVMD was observed between analyzed groups 6 months after CRT.

TABLE 1. Comparison of echocardiographic signs of dyssynchrony before and 6 months after cardiac resynchronization therapy between the analyzed groups.

\begin{tabular}{lccccc}
\hline \multicolumn{2}{c}{ ECG (N=70) } & \multicolumn{2}{c}{ ECHO (N=77) } \\
\hline Before CRT & 6 months after CRT & Before CRT & 6 months after CRT & \\
\hline AVd & $65(92.8 \%)$ & $26(37.1 \%)$ & $73(94.8 \%)$ & $14(18.1 \%)$ & $\mathrm{p}<0.01$ \\
\hline IVMD & $49(70 \%)$ & $26(37.1 \%)$ & $52(67.5 \%)$ & $11(14.2 \%)$ & $\mathrm{p}<0.01$ \\
\hline
\end{tabular}

SF - septal flash, AVd- atrioventricular dyssynchrony, IVMD- interventricular mechanical delay.

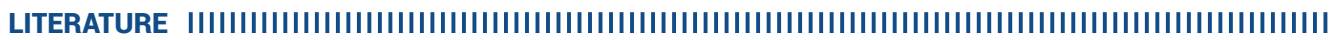

1. Gorcsan J 3rd, Marek JJ, Onishi T. The Contemporary Role of Echocardiography in Improving Patient Response to Cardiac Resynchronization Therapy. Curr Cardiovasc Imaging Rep. 2012 Dec:5(6):462-472. https://doi.org/10.1007/s12410-012-9172-2

2. van Everdingen WM, Schipper JC, van 't Sant J, Ramdat Misier K, Meine M, Cramer MJ. Echocardiography and cardiac resynchronisation therapy, friends or foes? Neth Heart J. 2016 Jan;24(1):25-38. https://doi.org/10.1007/s12471-015-0769-3 